\title{
Prediksi Potensi Erosi Kawasan Taman Hutan Raya Murhum Kota Kendari
}

\author{
Erfina \\ Universitas Sembilan belas November Kolaka; \\ e-mail: erfinafina575@yahoo.co.id
}

\begin{abstract}
Abstrak
Penelitian ini bertujuan untuk mevaluasi potensi erosi di Kawasan Taman Hutan Raya Murhum Kota Kendari. Metode yang digunakan adalah USLE dan menentukan arahan penggunaan lahan pada setiap unit lahan di lokasi penelitian. Metode pengambilan data di lapangan menggunakan metode survey dengan pendekatan analitik. Pengamatan intensif dilakukan pada setiap unit lahan yang menjadi sampel area dengan jarak observasi free survey. Hasil penelitian menunjukkan bahwa erosi aktual tertinggi terjadi pada unit lahan 14 sebesar 5496,42 ton/ha/th sedangkan erosi terendah terdapat pada unit 3 sebesar 1,11 ton/ha/th. Erosi Aktual (A) lebih besar dari erosi terbolehkan (ETOL) terjadi pada unit 1,4,5,8,10,11 dan 14, maka lahan ini diarahkan kepenggunaan lahan lain dan tindakan konservasi yang tepat. Hasil indeks bahaya erosi yang sangat tinggi terjadi pada unit lahan 4,5,7,8,10,11,14. Bagi unit lahan yang masih memiliki vegetasi lahan hutan alami seperti lahan 2,3,6,9 dan 13 perlu dipertahankan kondisi hutan alaminya melalui penegakan hukum dan pengawasan terhadap setiap bentuk dan ancaman yang dapat merusak keutuhan kawasan. Sedangkan unit lahan yang sudah terganggu vegetasi hutan alaminya perlu dihutankan kembali atau dikelola kembali untuk kemaslahatan masyarakat sekitar kawasan Tahura Murhum dengan jenis vegetasi bertingkat yang berfungsi konservasi dan bernilai ekonomi, pola tanam searah kontur dan pembuatan teras.
\end{abstract}

Kata kunci Erosi Aktual, Arahan penggunaan Lahan, Kendari

\section{PENDAHULUAN}

Meningkatnya jumlah penduduk seirama dengan laju pembangunan suatu kawasan, biasanya berhubungan erat dengan meningkatnya kebutuhan dan alokasi lahan untuk berbagai kegiatan, baik yang dilakukan oleh pemerintah maupun oleh masyarakat untuk pemenuhan kebutuhan sandang, pangan, perumahan dan sebagainya. Keadaan ini biasanya menimbulkan masalah yang berkaitan dengan alokasi peruntuhan lahan. Pengelolaan lahan yang tidak memperhatikan kaidah-kaidah konservasi tanah dan air dapat menimbulkan kerusakan tanah dan kemerosotan produktivitas tanah, serta tidak dapat dihindari akibat yang lebih jauh seperti terjadinya erosi, tanah longsor dan banjir pada musim hujan (Mey,2004).Lahan merupakan bagian dari bentang alam (Landscape) yang mencakup pengertian lingkungan fisik termaksud iklim, topografi/relief, hidrologi bahkan keadaan vegetasi alami (natural vegetation) yang semuannya secara potensial akan berpengaruh terhadap penggunaan lahan (FAO, 1976 dalam PPTA, 1993).

Erosi adalah suatu proses penghancuran, pelepasan material tanah oleh tumbukan air hujan dan penghanyutan material tanah yang terlepas tersebut oleh air permukaan (over land flow) menuju suatu sungai (canal) lalu terendapkan di badan-badan sungai atau danau, teluk (Mey, 2005). Secara umum ada lima faktor yang memengaruhi terjadinya erosi pada suatu kawasan yaitu iklim, tanah, topografi,vegetasi penutup tanah dan aktivitas manusia.

Kawasan Taman Hutan Raya Murhum Kota Kendari seluas 8.146 ha, memiliki potensi sumber daya alam berupa keanekaragaman flora dan fauna, tipe ekosistem dan objek wisata serta habitat berbagai satwa yang dilindungi Undang-Undang. Permasalahan yang terdapat dalam kawasan TAHURA Murhum adalah:1). Penyerobotan kawasan, untuk pemukiman dan perladangan belum memerhatikan aspek konservasi tanah baik untuk pemukiman maupun peladangan.2). Pengambilan kayu yang tak terencana,baik untuk kebutuhan sendiri maupun untuk diperjual belikan,3). Pemungutan kayu bakar secara tak terkendali dengan rata-rata tebangan pohon berdiameter $3-8 \mathrm{~cm}$. Kondisi ini akan memengaruhi kondisi hidrologi kawasan tersebut, dan jika tidak ditangani serius akan menyebabkan terjadinya peningkatan laju erosi yang berakibat pada pendangkalan teluk kendari. 
https://jurnal.unsulbar.ac.id/index.php/saintifik

Metode prediksi erosi juga merupakan alat untuk menilai apakah suatu program atau tindakan konservasi tanah telah mengurangi erosi dari suatu bidang tanah atau sutau daerah aliran sungai (DAS). Untuk menduga besarnya tingkat erosi yang terjadi digunakan metode USLE (Universal Soil Loss Equation) (Arsyad,1989). Sebagai berikut:

\section{A= R.K.L.S.C.P}

Keterangan:

A = Besarnya kehilangan tanah persatuan luas lahan (ton/ha/th)

$\mathrm{R}=$ Faktor erosivitas hujan

$\mathrm{K} \quad=$ Faktor erodibilitas tanah

$\mathrm{L} \quad=$ Faktor panjang lereng

$\mathrm{S} \quad=$ Faktor kemiringan lereng

$\mathrm{C} \quad=$ Faktor pengelolaan tanaman

$\mathrm{P} \quad=$ Faktor tindakan konservasi

Erosivitas hujan adalah tenaga potensial hujan yang menyebabkan erosi. Penentuan indeks faktor erosivitas hujan sangat tergantung dengan ketersediaan data iklim terutama curah hujan.Indeks faktor erosivitas curah hujan dalam penelitian ini ditentukan dengan menggunakan persamaan Bols (1978) dalam Seta (1991) yaitu:

$$
\sum \text { EI30 }=6,119 \text { Rain }^{1,21} \times \text { Days }^{-0,47} \times \text { Maxp }^{0,35}
$$

Faktor erodibilitas tanah $(\mathrm{K})$ menunjukkan resistensi partikel tanah terhadap pengelupasan dan transportasi partikel-partikel tanah tersebut oleh adanya energi kinetik air hujan. Besarnya erodibilitas atau resistensi tanah juga ditentukan oleh karakteristik tanah tanah seperti tekstur, stabilitas agregat tanah, kapasitas infiltrasi atau permeabilitas tanah, dan kandungan bahan organik tanah.

Nilai erodibilitas yang tinggi menandakan bahwa tanah pada area tersebut sangat rentan terhadap erosi yang dihasilkan oleh air hujan (Hasan,2017). Dampaknya adalah kehilangan lapisan tanah yang relative kaya unsur hara dan bahan organik, kemerosotan produktivitas tanah atau bahkan tidak dapat digunakan untuk berproduksi, pelumpuran atau sedimentasi dan pendangkalan sungai, faktor panjang lereng (L) dan Faktor kemiringan lereng $(\mathrm{S})$, dan faktor kemiringan dan panjang lereng merupakan nisbah antara erosi tanah dengan suatu panjang lereng tertentu terhadap erosi dari tanah dengan panjang lereng 22,1 meter dan kemiringan 9 persen dibawah keadaan identik. Faktor LS dapat ditentukan berdasarkan data hasil pengukuran panjang dan kemiringan lereng. Pengelolaan tanaman (C) merupakan nisbah antara tanah yang hilang pada pengelolaan tanaman tertentu dengan tanah yang hilang tanpa tanaman.

Nilai P merupakan faktor tindakan-tindakan khusus konservasi tanah yaitu nisbah antara besarnya erosi tanah yang diberi perlakuan konservasi khusus seperti pengolahan menurut kontur, pertanaman dalam strip atau teras, terhadapnya besarnya erosi dari tanah yang diolah searah lereng dalam keadaan identik (Arsyad,1989).

\section{METODE PENELITIAN}

Penelitian ini dilaksanakan di Kawasan Tahura Murhum Kota Kendari pada bulan Desember-Januari 2010. Metode yang digunakan adalah survey dengan pola pendekatan analitik.Pengamatan intensif dilakukan pada setiap unit lahan yang menjadi sampel area dengan jarak free survey. Dalam penelitian ini ada 4 tahap yang dilakukan. Tahap Persiapan penelitian Lapangan meliputi persiapan alat dan bahan yang dibutuhkan serta pembuatan peta lokasi penelitian. Tahap pengumpulan Data yaitu pengambilan dan pengukuran data langsung di lapangan yang menjadi lokasi sampel dan data penunjang lainnya berupa data iklim dan sosial ekonomi. Tahap Pengolahan Data yaitu mentabulasikan data lapangan dan hasil analisis sifat tanah di Laboratorium untuk menghitung besarnya kehilangan tanah akibat erosi dengan menggunakan metode USLE (Universal Soil Loss Equation) Arsyad (1989) rumus: 


\section{$A=$ R K L S C P,}

Erosi yang diperbolehkan (ETOL) toleransinya ditetapkan dengan menggunakan persamaan yang dijelaskan oleh wood dan Dent (1983) dalam Hardjowigeno dan sukmana (1995) yang memerhatikan kedalaman tanah minimun dan kecepatan proses pembentukan tanah dengan persamaan sebagai berikut:

\section{Mengukur Erosi yang diperbolehkan ETOL $=\underline{\mathbf{D}}_{\mathbf{E}}-\underline{\mathbf{D}}_{\mathbf{M I N}+\mathbf{L P T}}$ \\ MPT}

IBE (Indeks Bahaya Erosi) $=$ A/ETOL

CP maks untuk arahan penggunaan lahan $=$ ETOL/RKLS

Tahap Penyajian Hasil Penelitianmeliputi hasil akhir dari tabulasi data lapangan dan hasil analisis laboratorium yang disajikan dalam bab hasil dan pembahasan.

\section{HASIL DAN PEMBAHASAN}

Dalam prediksi erosi parameter-parameter yang ditentukan adalah erosivitas hujan(R), erodibilitas tanah $(\mathrm{K})$, faktor panjang dan kemiringan lereng (LS), pengelolaan tanaman (C) dan teknik konservasi (P). Penetapan batas tertinggi laju erosi yang ditoleransi adalah perlu oleh karena tidaklah mungkin menekan laju erosi menjadi nol dari tanah-tanah yang diusahakan untuk pertanian terutama pada tanah-tanah yang berlereng. Penetapan nilai erosi yang ditoleransi mempertimbangkan kedalaman efektif tanah, kedalaman tanah minimum, masa pakai tanah dan kecepatan proses pembentukan tanah (Arsyad, 1989).

Adapun rekap hasil erosi(A), erosi yang ditoleransi (ETOL), dan indeks bahaya erosi (IBE) disajikan pada tabel 1.

Tabel.1 Hasil perhitungan erosi

\begin{tabular}{|c|c|c|c|c|c|c|c|c|c|}
\hline \multirow{2}{*}{ UL } & \multirow{2}{*}{$\mathrm{R}$} & \multirow{2}{*}{ K } & \multirow{2}{*}{ LS } & \multirow{2}{*}{$\mathrm{C}$} & \multirow{2}{*}{$\mathrm{P}$} & \multirow{2}{*}{$\mathrm{A}(\mathrm{ton} / \mathrm{ha} / \mathrm{th})$} & \multirow{2}{*}{ ETOL } & \multicolumn{2}{|c|}{ IBE } \\
\hline & & & & & & & & Nilai & Harkat \\
\hline 1 & 1598,87 & 0,43 & 1,2 & 0,2 & 0,3 & 55,23 & 25,23 & 36,3 & ST \\
\hline 2 & 1598,87 & 0,51 & 1,1 & 0,001 & 1 & 0,90 & 25,24 & 35,5 & ST \\
\hline 3 & 1598,87 & 0,58 & 3,98 & 0,001 & 0,3 & 1,11 & 25,24 & 146,2 & ST \\
\hline 4 & 1598,87 & 0,38 & 3,24 & 0,2 & 1 & 393,54 & 25,1 & 78,4 & ST \\
\hline 5 & 1598,87 & 0,46 & 3,33 & 0,3 & 1 & 734,44 & 25,24 & 96,9 & ST \\
\hline 6 & 1598,87 & 0,21 & 9,67 & 0,001 & 1 & 3,25 & 25,09 & 129,3 & ST \\
\hline 7 & 1598,87 & 0,34 & 4,87 & 0,2 & 1 & 529,26 & 25,32 & 104,5 & ST \\
\hline 8 & 1598,87 & 0,44 & 11,98 & 0,3 & 1 & 2527,32 & 25,09 & 335,7 & ST \\
\hline 9 & 1598,87 & 0,2 & 27,06 & 0,001 & 1 & 8,65 & 24,98 & 346,2 & ST \\
\hline 10 & 1598,87 & 0,48 & 19,34 & 0,2 & 1 & 2967,28 & 25,32 & 585,9 & ST \\
\hline 11 & 1598,87 & 0,24 & 16,67 & 0,3 & 1 & 1918,22 & 25,32 & 252,5 & ST \\
\hline 12 & 1598,87 & 0,29 & 10,71 & 0,2 & 1 & 992,77 & 25,21 & 196,9 & ST \\
\hline 13 & 1598,87 & 0,37 & 14,27 & 0,001 & 1 & 8,44 & 25,14 & 335,6 & ST \\
\hline 14 & 1598,87 & 0,43 & 26,66 & 0,3 & 1 & 5496,42 & 25,24 & 724,2 & ST \\
\hline
\end{tabular}

Sumber.Data primer diolah Januari 2010

Hasil prediksi erosi menunjukkan bahwa erosi Aktual yang terjadi lebih besar dari erosi yang ditoleransi/terbolehkan yang terdapat pada unit lahan 1,4,5,7,8,10,11,12 dan 14.Kenyataan ini menunjukkan bahwa penggunaan lahan pada lokasi penelitian besar peluangnya mengakibatkan erosi yang membahayakan kelestarian sumber daya lahan pada berbagai penggunaan sehingga keberadaannya tidak dapat dipertahankan sehingga perlu adanya perubahan penggunaan lahan. 
Nilai erosi aktual lebih kecil dari erosi yang diperbolehkan/ditoleransi terdapat pada unit lahan 2,3,6,9 dan 13. Hal ini disebabkan karena penggunaan lahan hutan alam dengan serasah banyak sehingga mampu menahan pukulan air hujan melalui tajuk tanaman dan sistem kanopi tanaman. Sarief (1985) menjelaskan bahwa tanah yang ditutupi vegetasi umumnya mempunyai laju infiltrasi yang lebih besar dari pada permukaan tanah terbuka karena adanya perakaran tanaman yang menyebabkan porositas tanah lebih tinggi sehingga air lebih banyak mengalami infiltrasi kedalam tanah. Oleh karena itu,secara tidak langsung laju erosi menjadi lebih kecil.

Indeks bahaya erosi di semua unit lahan penelitian tergolong dalam indeks bahaya erosi yang sangat tinggi. Kenyataan ini menunjukkan bahwa penggunaan lahan pada lokasi penelitian besar peluangnya mengakibatkan erosi yang dapat membahayakan kelestarian lahan pada berbagai penggunaan sehingga keberadaanya tidak dapat dipertahankan dengan demikian perlu adanya arahan perubahan penggunaan lahan.

Tabel 2 Arahan Penggunaan Lahan

\begin{tabular}{|l|l|l|}
\hline UL & Arahan P.Lahan & CPmaks \\
\hline 1 & Kebun campuran dengan tajuk bertingkat, penutup tanah bervariasi kerapatan tinggi & 0,001 \\
\hline 2 & Dihutankan & 0,001 \\
\hline 3 & Dihutankan & 0,001 \\
\hline 4 & Kebun campuran dengan tajuk bertingkat, penutup tanah bervariasi kerapatan tinggi & 0,01 \\
\hline 5 & Dihutankan & 0,001 \\
\hline 6 & Dihutankan & 0,001 \\
\hline 7 & Pengolahan tanah dengan penanaman kontur kemiringan >20\% & 0,009 \\
\hline 8 & Dihutankan & 0,001 \\
\hline 9 & Dihutankan & 0,001 \\
\hline 10 & Dihutankan & 0,001 \\
\hline 11 & Dihutankan & 0,001 \\
\hline 12 & Dihutankan & 0,001 \\
\hline 13 & Dihutankan & 0,001 \\
\hline 14 & Dihutankan & 0,001 \\
\hline
\end{tabular}

Menekan laju erosi yang besar agar menjadi sama atau lebih kecil dari erosi yang ditoleransikan, maka perlu dilakukan pengelolaan tanaman dan tindakan konservasi tanah yang cocok untuk diterapkan. Tujuan pemilihan pengelolaan tanaman dan tindakan konservasi tanah adalah agar faktor $\mathrm{C}$ dan $\mathrm{P}$ yang dipilih mampu mengurangi tingginya nilai erosi.

\section{KESIMPULAN}

Dari hasil penelitian dapat disimpulkan bahwa Erosi Aktual tertinggi terjadi pada unit lahan 10 dan 14 yaitu sebesar 2967,28 ton/ha/th dan 5496,42 ton/ha/th, sedangkan nilai erosi terendah terjadi pada unit lahan 3 yaitu sebesar 1,11 ton/ha/th. Selain itu, Erosi Aktual (A) lebih besar dari eosi diperbolehkan (ETOL) terjadi pada unit lahan 1,4,5,8,10,11 dan 14 maka lahan ini perlu diarahkan kepenggunaan lahan hutan dan tindakan konservasi yang tepat.Secara umum Indeks Bahaya Erosi (IBE) di Kawasan Taman Hutan Raya Murhum Kota Kendari tergolong sangat tinggi yang terjadi pada semua unit lahan. Kesimpulan dapat berupa paragraf, namun sebaiknya berbentuk point-point dengan menggunakan numbering atau bullet.

\section{DAFTAR PUSTAKA}

Arsyad, S. 1989. Konservasi Tanah dan Air. IPB Press.Bogor

Hardjowigeno, S, dan S. Sukmana, 1995. Menentukan Tingkat Bahaya Erosi. Second Land Resource Evaluation and Planning Project. ADB Loan. No. 1099 INO.Pusat Penelitian Tanah dan Agroklimat. Bogor. 
https://jurnal.unsulbar.ac.id/index.php/saintifik

Mey, D. 2004. Perubahan Penggunaan Lahan dan Dampaknya Terhadap Kondisi Hidrologi. Jurnal Soil Enviroment. Volume 2, Nomor 2 Edisi Agustus 2004, ISSN 1412-9108. Halaman 6-12.

Mey, D. 2005. Geomorfologi dan Analisis Landscape. Materi Kuliah Program Studi Ilmu Tanah, Fakultas Pertanian Universitas Haluoleo. Kendari.

PPTA. 1993. Petunjuk Teknis Evaluasi Lahan. Pusat-Pusat Penelitian Tanah dan Agroklimat Kerjasama dengan Proyek Pembangunan Penelitian Pertanian nasional, Badan Penelitian dan Pengembangan Pertanian. Departemen Pertanian. Bogor.

Hasan, H. 2017. Zonasi Tingkat Erodibilitas tanah Pada Area Reklamasi Tambang PT.Bahrianto Ekatama Kabupaten Kutai Barat Kalimantan Timur.Fakultas Teknik.Universitas Mulawarman.

Sarief, S.E., 1985. Konservasi Tanah dan Air. Pustaka Buana. Bandung

Seta, A. K., 1991. Konservasi Sumberdaya Tanah dan Air. Kalam Mulia. Jakarta 